\title{
Determination of Multiple Antibiotic and Heavy Metal Resistance of the Bacteria Isolated from the Küçükçekmece Lagoon, Turkey
}

\author{
Ayten Kimiran-Erdem*, Elif Özlem Arslan-Aydoğdu', \\ Sevan Gürün², Ömer Altun ${ }^{3}$ \\ 'Department of Biology, Section of Fundamental and Industrial Microbiology, Faculty of Science, \\ Istanbul University, 34134 Vezneciler, Istanbul, Turkey \\ ${ }^{2}$ Department of Marine Biology, Fisheries Faculty, Istanbul University, Istanbul, Turkey \\ ${ }^{3}$ Department of Biology, Section of Hydrobiology, Faculty of Science, Istanbul University, \\ 34134 Vezneciler, Istanbul, Turkey
}

Received: 30 June 2014

Accepted: 3 August 2014

\begin{abstract}
One hundred strains of Gram-negative bacteria were isolated from a brackish water Lagoon, Küçükçekmece in Istanbul-Turkey. Identification studies showed that $31 \%$ of the isolated bacteria were Escherichia coli, 28\% were Citrobacter, and 12\% were Enterobacter. Antibiotic and heavy metal resistances exhibited by these bacteria were evaluated. In antibiotic susceptibility tests, $68 \%$ of the isolates appeared to be resistant to vancomycin, while $38 \%$ was resistant to erythromycin, $23 \%$ to penicilin $\mathrm{G}, 19 \%$ to ampicillin, $13 \%$ to nalidixic acid and streptomycin, $7 \%$ to chloramphenicol, $5 \%$ to amikacin, $2 \%$ to gentamycin, and $1 \%$ to kanamycin. Most of the isolates tolerated various concentrations of heavy metals, and the minimum inhibitory concentrations (MIC) ranged from $20 \mu \mathrm{g} / \mathrm{ml}$ to $>5000 \mu \mathrm{g} / \mathrm{ml}$. In terms of heavy metal sensitivity, $98 \%$ of the isolates were resistant to $\mathrm{Fe}, 95 \%$ to $\mathrm{Cd}, 85 \%$ to $\mathrm{Co}, 83 \%$ to $\mathrm{Cu}$ and $\mathrm{Zn}$, and $74 \%$ to Ni. When antibioticheavy metals multiresistance index was examined, it was determined that the multiple heavy metal resistance (MHMR) index was remarkably high for the bacteria, while the multiple antibiotic resistance (MAR) index was low according to heavy metal resistance.

It was demonstrated that the bacteria isolated from Küçükçekmece Lagoon were highly resistant to antibiotics and heavy metals. It was concluded that if the wastewater discharge to the Lagoon is not regulated, resistance gene transfers into the bacteria hosted normally in human microbiota could create significant health issues.
\end{abstract}

Keywords: multiple antibiotic resistance, heavy metals, Gram-negative bacteria, coastal lagoon

\section{Introduction}

Küçükçekmece Lagoon is utilized as a recreational area for the locals. However, as a result of increasing population and industrialization, it was contaminated with faecal efflu-

*e-mail: kimiran@istanbul.edu.tr ents and heavy metals. Thus, it poses a significant risk for public health [1]. Human and animal pathogenic and potentially pathogenic bacteria are continually introduced with wastewater into the water bodies [2]. Waters contaminated with faecal human and cattle waste are generally considered a greater risk for human health [3, 4]. Although there are large numbers of pathogens in the water, isolation of 
Table 1. MHMR index of isolates.

\begin{tabular}{|c|c|c|}
\hline MHMR index & Number of isolates & \% Distribution \\
\hline 0.0 & 0.0 & 0.00 \\
\hline 0.1 & 0.0 & 0.00 \\
\hline 0.2 & 0.0 & 0.00 \\
\hline 0.3 & 1.0 & 0.96 \\
\hline 0.4 & 2.0 & 1.92 \\
\hline 0.5 & 0.0 & 0.00 \\
\hline 0.6 & 3.0 & 2.89 \\
\hline 0.7 & 29.0 & 27.89 \\
\hline 0.8 & 0.0 & 0.00 \\
\hline 0.9 & 35.0 & 33.65 \\
\hline 1.0 & 34.0 & 32.69 \\
\hline
\end{tabular}

these bacteria is difficult. Therefore, indicator microorganisms such as faecal and total coliforms and source discriminant-faecal streptococci have been used for many years to indicate fecal pollution and the presence of the pathogenic bacteria in natural water bodies $[4,5]$. Counting indicator microorganisms, as the traditional method of health risk assessment for waterborne pathogens, was also the first method for tracking the sources of faecal pollution [6]. However, this method is not reliable to identify the source of faecal contamination. Thus, a more efficient method is needed [7].

There are several approaches to identify the sources of faecal pollution [4, 6]. Microbial Source Tracking (MST) is a method used to determine the sources of faecal bacteria and establish whether faecal bacteria were introduced into water bodies through human, wildlife, agricultural, or pet wastes. Multiple antibiotic resistance (MAR) determina- tion is also employed most commonly with MST studies. In MAR studies, bacteria are tested for resistance against various antibiotics $[4,6]$. The patterns of antibiotic resistance have been used to identify sources of faecal pollution in the water. The MAR method may successfuly differentiate between human and animal sources and between certain types of animal sources. The antibiotic resistance of patterns of bacteria are influenced by selective pressure, thus may be different in various georaphical areas and may vary over time [8].

Water bodies such as seas and lagoons may also be polluted by heavy metals introduced by household and industrial wastes. Increased heavy metal pollution is not only manmade, but also is a result of natural activities. These toxic wastes pose potential ecological risks. Survival and reproduction capability of microorganisms in an ecosystem polluted with heavy metal wastes is determined by their genetic structure or physiological adaptation capabilities. $[9,10]$. Certain species develop physiological adaptation while others become resistant to toxic metals [9].

Heavy metals in the environment might cause meaningful changes in the structure and function of microbial communities. Gram-negative and Gram-positive bacteria may become resistant to heavy metals. This resistance may indicate the level of contamination and the exposure of bacteria to heavy metals. Recently, various studies reported the emergence of antibiotic-resistant bacteria due to crossresistance $[11,12]$.

Heavy metal resistance is interconnected with single or multiple antibiotic resistances in bacteria. Studies with Escherichia coli, Salmonella typhimurium, and Pseudomonas aeruginosa demonstrated such kind of a relationship [13].

This study focuses on:

(i) identification of the Gram-negative bacteria isolated in Küçükçekmece Lagoon

(ii) to determine the level of antibiotic resistance and the heavy metal resistance of the bacteria.

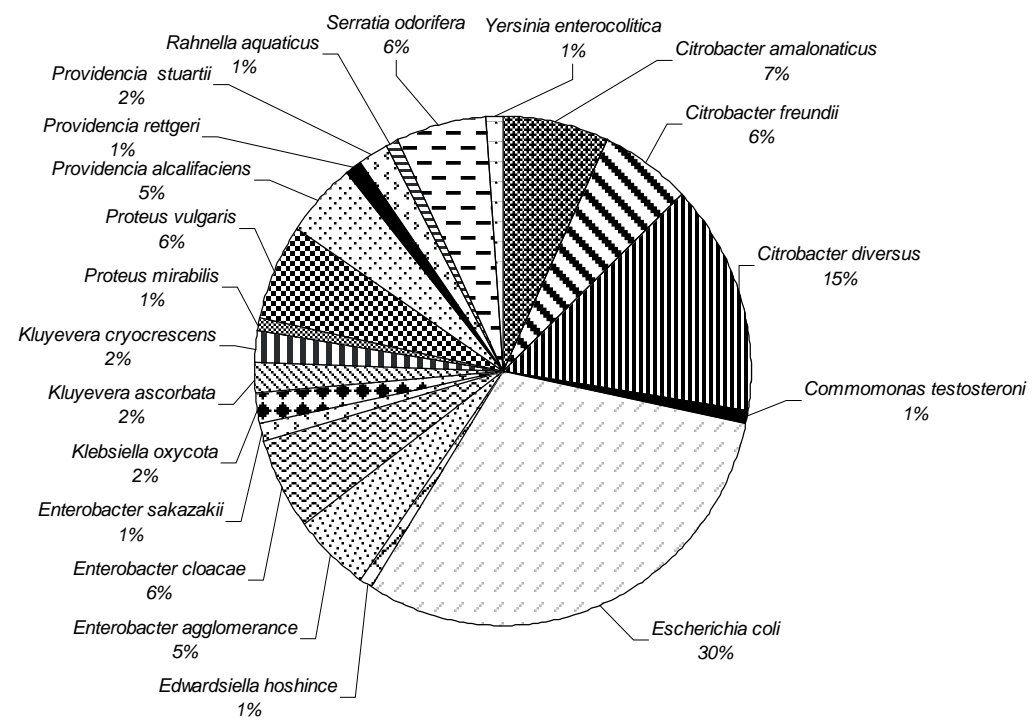

Fig. 1. Distribution of Gram-negative bacteria isolated from Küçükçekmece Lagoon. 


\section{Material and Methods}

\section{Sample Collection}

Water samples were collected every two months for a year from Küçükçekmece Lagoon, located on the western outskirts of Istanbul [14]. Water samples taken into sterile glass bottles were immediately transported to the laboratory in the cooling cabin and were examined bacteriologically within $4-6 \mathrm{~h}$ after collection [15].

\section{Isolation and Identification of Bacteria}

Gram-negative bacteria were isolated from water samples via standard membrane filtration methods [15] using Endo-NKS membranes (Sartorius, Goettingen, Germany). Bacteria grown on Endo-NKS membranes were immediately stained by the Gram's Method to verify Gram-negative rods. Strains determined as Gram-negative rod bacteria were selected and subcultured on nutrient agar at $37^{\circ} \mathrm{C}$ for $24 \mathrm{~h}$ to determine oxidase activity and for identification studies. Bacterial isolates were identified according to their morphological, cultural, and biochemical characteristics using the identification criteria of Bergey's Manual [16]. Gram-negative rod-shaped fermentative strains were characterized using API20E strips (Biomeriux, France). Stock cultures were frozen in $10 \%$ glycerol and stored at $-20^{\circ} \mathrm{C}$ [17].

\section{Resistance Tests}

\section{Media}

Mueller-Hinton Agar (MHA) and Mueller-Hinton Broth (MHB) were used as media in both antibiotic and heavy metal resistance tests [18].

\section{Preparation of Bacterial Inocula}

Strains were incubated at $37^{\circ} \mathrm{C}$ for $18 \mathrm{~h}$ on MHA and then used as inocula. Their concentrations were turbidimetrically adjusted in MHB to $10^{8}$ colony forming unit (CFU) $\mathrm{ml}^{-1}$ for antibiotic tests and to $10^{5} \mathrm{CFU} \mathrm{ml}{ }^{-1}$ for heavy metal resistance tests. The number of bacteria was confirmed by plate counts. All of the experiments were conducted in triplicate [19].

\section{Resistance to Antibiotics}

Antibiotic resistance of the 100 isolates was determined by Kirby-Bauer disc diffusion method [20] using the following discs: Ampicillin $10 \mu \mathrm{g}(\mathrm{AP})$, penicilin G 10 units (PG), gentamycin $10 \mu \mathrm{g}(\mathrm{GM})$, streptomycin $10 \mu \mathrm{g}(\mathrm{S})$, chloramphenicol $10 \mu \mathrm{g}(\mathrm{C})$, erythromycin $15 \mu \mathrm{g}(\mathrm{E})$, kanamycin $30 \mu \mathrm{g}(\mathrm{K})$, amikacin $30 \mu \mathrm{g}(\mathrm{AK})$, nalidixic acid $30 \mu \mathrm{g}$ (NA), and vancomycin $30 \mu \mathrm{g}$ (VA). All of the antibiotics (on $6 \mathrm{~mm}$ diameter discs) were obtained from Oxoid (Hampshire, England). Inhibition zones formed around antibiotic discs were evaluated according to the Clinical and Laboratory Standards Institute (CLSI) criteria [21].
Table 2. MAR index of isolates.

\begin{tabular}{|c|c|c|}
\hline MAR index & Number of isolates & \% Distribution \\
\hline 0.0 & 11.0 & 10.57 \\
\hline 0.1 & 34.0 & 32.69 \\
\hline 0.2 & 33.0 & 31.73 \\
\hline 0.3 & 14.0 & 13.46 \\
\hline 0.4 & 6.0 & 5.77 \\
\hline 0.5 & 5.0 & 4.81 \\
\hline 0.6 & 1.0 & 0.96 \\
\hline 0.7 & 0.0 & 0.00 \\
\hline 0.8 & 0.0 & 0.00 \\
\hline 0.9 & 0.0 & 0.00 \\
\hline 1.0 & 0.0 & 0.00 \\
\hline
\end{tabular}

Escherichia coli ATCC 25922 was used as a control strain for verification of the antibacterial effect of the discs [11].

For all the isolates, MAR index values were calculated as $a / b$, where ' $a$ ' represents the number of antibiotics to which the isolate was resistant and ' $b$ ' represents the number of antibiotics the isolate was tested against [22]. When MAR index value was $>0.2$, it indicated that the isolate originated from high-risk contamination sources such as human wastes, commercial poultry farms, and swine and dairy cattle where antibiotics are very often used. MAR index value $\leq 0.2$ indicated that the strain was originated from animals in which antibiotics were seldom or never used [11, 22, 23].

\section{Resistance to Heavy Metal Salts}

Amounts of heavy metals used in the experiments were selected according to atomic absorption spectrum measurement results. In order to obtain different concentrations of $\mathrm{Zn}, \mathrm{Fe}, \mathrm{Cd}, \mathrm{Cr}, \mathrm{Co}, \mathrm{Cu}$, and $\mathrm{Ni}$ ions, samples were diluted with sterile deionized water. Microdilution method was followed with minor modifications for the determination of heavy metal resistances against zinc sulphate $\left(\mathrm{ZnSO}_{4} \cdot 7 \mathrm{H}_{2} \mathrm{O}\right)$, ferric chloride $\left(\mathrm{FeCl}_{3} \cdot 6 \mathrm{H}_{2} \mathrm{O}\right)$, cadmium chloride $\left(\mathrm{CdCl}_{2} \cdot 2 \mathrm{H}_{2} \mathrm{O}\right)$, potassium chromate $\left(\mathrm{K}_{2} \mathrm{CrO}_{4}\right)$, cobalt chloride $\left(\mathrm{CoCl}_{2} \cdot 6 \mathrm{H}_{2} \mathrm{O}\right)$, copper sulphate $\left(\mathrm{CuSO}_{4} \cdot 5 \mathrm{H}_{2} \mathrm{O}\right)$, and nickel chloride $\left(\mathrm{NiCl}_{2} \cdot 6 \mathrm{H}_{2} \mathrm{O}\right)$ [24]. In U-well micro-titer plates, dilutions of heavy metals were prepared and bacterial inocula were then added to each well. Before the addition of bacterial inocula, no precipitation was observed. Plates were incubated at $37^{\circ} \mathrm{C}$ for $24 \mathrm{~h}$, and examined for visual turbidity. The lowest metal salt concentration that was capable of inhibiting bacterial growth (indicated by the lack of turbidity) was accepted as the minimum inhibitory concentration (MIC). Samples of $10 \mu l$ were drawn from the wells with zero turbidity and subcultured on MHA plates to determine bactericidal concentration. 
The isolates were considered resistant when the MIC values exceeded that of the E. coli K-12 control strain [11, 25].

Multiple heavy metal resistance (MHMR) index was calculated as described above for the MAR index.

\section{Results}

Fig. 1 summarizes the generic diversity of Gram-negative rods isolated from the water samples of the Küçükçekmece Lagoon. A total of 20 bacterial species were detected in the 100 isolates. It was also determined that among the isolates, Escherichia coli and Citrobacter diversus were at relatively high frequencies.

In antibiotic susceptibility tests, $68 \%$ of the isolates were resistant to VA, $38 \%$ to $\mathrm{E}, 23 \%$ to $\mathrm{PG}, 19 \%$ to $\mathrm{AP}, 13 \%$ to NA and $\mathrm{S}, 7 \%$ to $\mathrm{C}, 5 \%$ to $\mathrm{AK}, 2 \%$ to $\mathrm{GM}$, and $1 \%$ to $\mathrm{K}$.

MIC levels were in the ranges of $160-2500 \mu \mathrm{g} / \mathrm{ml}, 80$ $160 \mu \mathrm{g} / \mathrm{ml}, 1250-5000 \mu \mathrm{g} / \mathrm{ml}, 20-2500 \mu \mathrm{g} / \mathrm{ml}, 80-320$ $\mu \mathrm{g} / \mathrm{ml}, 40-5000 \mu \mathrm{g} / \mathrm{ml}$, and $80-630 \mu \mathrm{g} / \mathrm{ml}$ for $\mathrm{Cu}, \mathrm{Zn}, \mathrm{Fe}$, $\mathrm{Cd}, \mathrm{Co}, \mathrm{Cr}$, and $\mathrm{Ni}$, respectively. The study of heavy metal sensitivity showed that $98 \%$ of the isolates was resistant to $\mathrm{Fe}, 95 \%$ to $\mathrm{Cd}, 85 \%$ to $\mathrm{Co}, 83 \%$ to $\mathrm{Cu}$ and $\mathrm{Zn}$, and $74 \%$ to $\mathrm{Ni}$.

When antibiotic-heavy metals multiresistance index was examined, it was determined that the MHMR index was remarkably high for the bacteria (Table 1), while the MAR index was low according to heavy metal resistance (Table 2).

When multiple antibiotic and heavy metal resistances were examined at the species level, it was shown that the percentage of MHMR was high for all bacteria. MAR index was $\geq 0.2$ for 11 out of the 20 species (Table 3 ).

As the antibiotic-resistance was pertinent with heavy metal resistance, all the isolates were tested for sensitivity to 7 different heavy metals. It was found that among the isolates, those that exhibit resistance to antibiotics (particularly to $\mathrm{C}, \mathrm{PG}, \mathrm{AP}, \mathrm{GM}, \mathrm{K}, \mathrm{AK}$, and $\mathrm{E}$ ) were also resistant to Fe (\%100) (Table 4).

\section{Discussion}

In the current study, among a total of 100 isolates, 20 species of Gram-negative bacteria were identified (Fig. 1). Escherichia coli prevalently comprised $31 \%$ of them. The following most common bacterial genus encountered were Citrobacter (28\%) and Enterobacter (12\%).

Alvero (1987) isolated 87 different strains (comprised of Acinetobacter, Aeromonas, Bacillus, Enterobacter, Flavobacterium, Micrococcus, and Pseudomonas) from two lakes possessing different eutrification levels [26].

Lobova et al. [27] studied the bacterial diversity in Shira Lake, and reported a dominant presence of Pseudomonas sp., Acinetobacter sp., and Flavobacteria, in addition to Halococcus, Bacillus, and Escherichia genera.

Saleem et al. [28] studied eight separate locations in Dal Lake and isolated 894 strains. Bacterial diversity was
Table 3. Evaluation of MHMR and MAR indices at the species level.

\begin{tabular}{|l|c|c|c|}
\hline \multicolumn{1}{|c|}{ Species name } & $\begin{array}{c}\text { \% of } \\
\text { isolates }\end{array}$ & $\begin{array}{c}\text { MHMR } \\
\text { index }\end{array}$ & $\begin{array}{c}\text { MAR } \\
\text { index }\end{array}$ \\
\hline Citrobacter amalonaticus & 7 & 0.78 & 0.09 \\
\hline Citrobacter freundii & 6 & 0.86 & 0.25 \\
\hline Citrobacter diversus & 15 & 0.88 & 0.17 \\
\hline Commomonas testosteroni & 1 & 1.00 & 0.60 \\
\hline Escherichia coli & 31 & 0.82 & 0.14 \\
\hline Edwardsiella hoshince & 1 & 1.00 & 0.10 \\
\hline Enterobacter agglomerance & 5 & 0.80 & 0.18 \\
\hline Enterobacter cloacae & 6 & 0.91 & 0.18 \\
\hline Enterobacter sakazakii & 1 & 1.00 & 0.30 \\
\hline Klebsiella oxycota & 2 & 0.43 & 0.30 \\
\hline Kluyevera ascorbata & 2 & 0.71 & 0.30 \\
\hline Kluyevera cryocrescens & 2 & 0.71 & 0.05 \\
\hline Proteus mirabilis & 1 & 0.57 & 0.50 \\
\hline Proteus vulgaris & 6 & 0.91 & 0.35 \\
\hline Providencia alcalifaciens & 5 & 0.89 & 0.18 \\
\hline Providencia rettgeri & 1 & 0.43 & 0.40 \\
\hline Providencia stuartii & 2 & 0.93 & 0.35 \\
\hline Rahnella aquaticus & 1 & 0.86 & 0.30 \\
\hline Serratia odorifera & 6 & 0.86 & 0.12 \\
\hline Yersinia enterocolitica & 1 & 0.86 & 0.40 \\
\hline
\end{tabular}

as follows: Escherichia coli (15.77\%), Enterobacter aerogenes (12.19\%), Bacillus spp. (11.96\%), Staphylococcus aureus (10.85\%), Micrococcus luteus (10.17\%), Pseudomonas aeruginosa (8.27\%), Klebsiella pneumoniae (6.71\%), Vibrio cholerae (6.59\%), Salmonella spp. (6.15\%), Serratia marcescens (5.92\%), and Citrobacter freundii $(5.59 \%)$.

In other research, Pontes et al. [29] isolated 272 Gramnegative bacteria and found the dominant genera to be Acinetobacter, Enterobacter, and Pseudomonas.

Sivri et al. [1], in another study in Küçükçekmece Lagoon, isolated 232 bacteria and the prevalent species was Escherichia coli followed by Citrobacter and Enterobacter. These results appear to confirm those of the current study.

Overall, studies on lake bacterial diversity confirm that Escherichia coli, Citrobacter, Enterobacter, Pseudomonas sp., Acinetobacter sp., and Flavobacteria are commonly isolated microorganisms with the prevalency varying with the characteristics of the lakes.

Occurrence of Escherichia coli as an indicator of faecal pollution is related to environmental conditions and industrial influences. It is an allocutaneous bacterium, and usually encountered in lakes exposed to human impact. 
Table 4. Correlation between antibiotic and heavy metal resistance of bacteria isolated from the Küçükçekmece Lagoon water samples.

\begin{tabular}{|c|c|c|c|c|c|c|c|c|}
\hline \multirow{2}{*}{ Antibiotics } & \multirow{2}{*}{$\begin{array}{c}\text { No. of resistant } \\
\text { isolates }\end{array}$} & \multicolumn{9}{|c|}{ Resistance to heavy metals (\%) } \\
\cline { 3 - 10 } & & Zn & Co & Cr & Fe & Ni & Cd & Cu \\
\hline NA & 13 & 69 & 69 & 69 & 92 & 62 & 77 & 77 \\
\hline C & 7 & 86 & 100 & 29 & 100 & 100 & 100 & 100 \\
\hline VA & 71 & 85 & 85 & 63 & 99 & 79 & 97 & 89 \\
\hline PG & 24 & 75 & 83 & 46 & 100 & 83 & 96 & 83 \\
\hline AP & 20 & 75 & 80 & 60 & 100 & 85 & 95 & 90 \\
\hline GM & 2 & 100 & 100 & 50 & 100 & 50 & 50 & 100 \\
\hline S & 14 & 64 & 79 & 64 & 93 & 71 & 93 & 79 \\
\hline K & 1 & 100 & 100 & 0 & 100 & 100 & 100 & 100 \\
\hline AK & 5 & 80 & 60 & 100 & 100 & 40 & 60 & 60 \\
\hline E & 40 & 83 & 83 & 70 & 100 & 70 & 95 & 75 \\
\hline
\end{tabular}

The Küçükçekmece Lagoon is reportedly exposed to industrial and antropogenic pollution [1]. The majority of the bacteria isolated in this study was from the Enterobacteriacea family. Besides, results of the studies including the current one state that commonly encountered Citrobacter and Enterobacter were present in water bodies and soil even in the absence of Escherichia coli. These bacteria were more resistant to environmental conditions than E. coli. $[1,16]$. In other reports, it was stated that autocutaneous bacteria such as Pseudomonas, Acinetobacter, and Flavobacteria were isolated and exhibited high levels of antibiotic resistance $[9,26,30]$.

A plethora of papers investigated the bacteria resistant to antibiotics in aquatic environments $[1,8,9,11,13,19$, 26-29, 31]. In different environments, bacteria are expected to experience distinct selective pressure for antibiotic resistance, hence various patterns of antibiotic resistance is acquired [32]. In fact, it was stated that for the non-aquatic organisms, obviously the density of antibiotic-resistance organisms in freshwater varies with the proximity to areas with increased antibiotic consumption, metal pollution, and between seasons, being more frequently found in rainy seasons [2].

It was found that $68 \%, 38 \%, 23 \%, 19 \%, 13 \%, 7 \%, 5 \%$, $2 \%$, and $1 \%$ of the isolates were resistant to VA, E, PG, AP, $\mathrm{NA}+\mathrm{S}, \mathrm{C}, \mathrm{AK}, \mathrm{GM}$, and $\mathrm{K}$, respectively.

In the current study, isolation of the Enterobacteriacae family was targeted. Isolated allocutaneous bacteria such as Escherichia coli, Klebsiella, and Enterobacter are resistant to antibiotics and they can transfer the resistance genes to autocutaneous bacteria via lateral transfer, thus, contribute to distribution of multiple antibiotic resistance.

Alvero stated that $71 \%$ of the isolates were resistant to one or more antibiotics, $44 \%$ of the strains exhibited multiple resistance. Moreover, antibiotic resistance was, to an extent, related to genera but not related to habitat, and the resistance was not directly related to sewer-based contamination [26].
Sivri et al. [1] showed that antibiotic resistance levels of bacteria isolated in Küçükçekmece Lagoon were as follows: AM (76.3\%), AMC (36.9\%), S (20.7\%), NA ve TE (16.8\%), CAZ (16.4\%), CM (9.4\%), I (6.8\%), and AC (6.4\%) [1]. When compared to the results of the current study, it appears that antibiotic resistance has further increased in Küçükçekmece Lagoon. The results suggest that either the level of faecal contamination increased in the Lagoon, or antibiotic-resistant bacteria transferred the resistance genes to other bacteria.

Multiple antibiotic resistance (MAR) test is a traditional one, and has already been used to differentiate sources of faecal pollution. By examining the multiple antibiotic resistance properties of the indicator microorganisms, it is possible to understand whether there is contamination from human or animal origins. Parveen et al. [33] stated that MAR index was very high in E. coli of human origin, while it was low in Escherichia coli of animal origin.

MAR index analyses of the isolated bacteria showed that Escherichia coli (also known as faecal origin bacteria) had a rather low MAR index (0.14). It should be noted that Escherichia coli is found in great quantities in the intestines of humans and warm-blooded animals. For the isolated Escherichia coli, a MAR index less than 0.2 suggests that strain was originated from waste of animals on which antibiotics were seldom or never used.

However, MAR indexes calculated for Citrobacter freundii (0.25), Commomonas testosteroni (0.6), Enterobacter cloacae (0.3), Klebsiella oxycota (0.3), Kluyevera ascorbata (0.3), Proteus mirabilis (0.5), Proteus vulgaris (0.35), Providencia rettgeri (0.4), Providencia stuartii (0.35), Rahnella aquaticus (0.3), and Yersinia enterocolitica (0.4) were notably high (Table 3 ). Most of these bacteria are members of the Enterobacteriaceae family, and they exhibit different antibiotic resistance phenotypes. Nevertheless, MAR index of $K$. oxycota with faecal origin is also high (0.3). Klebsiella oxytoca is an opportunistic pathogen responsible for health care-associated infections [34]. 
MAR index values $>0.2$ indicate that the isolates must have originated from an environment where antibiotics are often used. When the isolated bacteria were evaluated in terms of MAR index, it was found that Küçükçekmece Lagoon was not exposed to significant antibiotic contamination. Determination of the multiple antibiotic resistance properties not only helps better understand the epidemiological aspects, but also aids to decrease the risk of new outbreaks. However, it should be noted that antibiotic resistance is often carried out on plasmids, which could be lost from cells through cultivation and storage, or even by changes in environmental conditions. In addition, strains may show differences in specific sensitivities due to variable antibiotic use among humans and animals, and may change the antibiotic resistance pattern [4].

Heavy metal resistance is also important to indicate that water environments such as Küçükçekmece Lagoon are industrially polluted. Although there are various studies providing information about the pollution source of the MAR index, an index showing the relationship between heavy metal pollution and multiple heavy metal resistance (MHMR) has not been found. However, it was stated in several reports that bacteria showing heavy metal resistance could be used as an indicator in environments exposed to industrial pollution [11]. It has been suggested that the combination of antibiotic and metal resistance may not be a fortuitous phenomenon and bacterial resistance against heavy metals appears to be directly related to the presence of these elements as environmental pollutants [18, 19, 35]. Generally, exposure to a heavy metal increases the level of resistance of the bacterial community toward that metal. Clean environments might provide a safe haven for microorganisms that have become metal-resistant, or those adapted to high metal concentrations. However, the incidence of plasmid-containing strains is higher in polluted areas [9]. Therefore, the MHMR index was assessed as well as MAR index. In the present study, when multiple antibiotic and heavy metal resistances were examined at the species level, it was shown that the percentage of MHMR was high for all bacteria. Consequently, it was found that the examined Lagoon is exposed to serious heavy metal pollution. Indeed, this is in agreement with the results of Altun et al. [11], who reported that the mean concentrations of heavy metals were high values, which are not typical of natural waters. Evidently, the MHMR index can be effectively used for evaluation of heavy metal pollution.

In another study, Matyar et al. [11] demonstrated that most of the bacteria isolated from seawater samples in Iskenderun Bay could tolerate various concentrations of heavy metals. The minimal inhibitory concentration for heavy metals varied between 12.5-3200 $\mu \mathrm{g} / \mathrm{ml}$. Bacteria obtained from samples of sea water were $69.4 \%$ resistant to cadmium (strong resistance), and were $2 \%$ resistant to manganese (weak resistance). The resistant strains recovered from seawater samples were also highly resistant to streptomycin, ampicillin, and trimethoprim-sulphamethoxazole [11].

It was shown by McArthur and Tuckfield that mercury concentration in sea sediments was directly correlated with the antibiotic resistance of the bacteria [36]. Another study by Mgbemena et al. [37] demonstrated a correlation between the antibiotic resistance and iron concentration of the environment in Escherichia coli, while there was another correlation between antibiotic resistance and zinc concentration in Proteus bacteria. The current study also demonstrates a similar relationship between antibiotic resistance and iron levels. Verifying results were obtained in various other studies [13, 19, 38-41]. It is believed that the correlation between heavy metal and antibiotic resistance is due to the physical connections in genes. With respect to heavy metal-sensitive strains, heavy metal-resistant strains are more inclined to be resistant to antibiotics as well.

Microorganisms evolve to tolerate heavy metals. In the contaminated environments, these organisms use heavy metals for reproduction; thus, they could be valuable candidates for bioremediation of metal-contaminated habitats. However, heavy metal resistance tends to contribute to undesired side effects such as increased antibiotic resistance, rendering this idea useless.

Thus, certain measures should be taken in order to clean Küçükçekmece Lagoon and prevent its further pollution, i.e., pollution sources should be determined, wastewater discharge to streams and creeks that feed the Lagoon must be prevented, and new construction that will be considered around the lake should be environmentally friendly.

The current study reports novel and significant information since it is the first study simultaneously analyzing antibiotic and heavy metal resistance of Gram-negative bacteria from Küçükçekmece Lagoon.

Finally, antibiotic and heavy metal susceptibility tests conducted on environmental bacterial strains will help determine epidemiological consequences and effects of toxic pollutants. Further studies are planned to better understand the mechanisms of resistance in these bacteria. Moreover, the importance of plasmids in antibiotic and heavy metal resistance will be investigated.

\section{References}

1. SIVRI N., SANDALLI, C., OZGUMUS O.B., ÇOLAKOGLU F., DOGAN D. Antibiotic resistance profiles of enteric bacteria isolated from Kucukcekmece Lagoon (Istanbul-Turkey) Türk. J. Fish. Aquat. Sc. 12, 699, 2012.

2. BAQUERO F., MARTINEZ J.L., CANTO N.R. Antibiotics and antibiotic resistance in water environments. Curr. Opin. Biotech. 19, 260, 2008.

3. HARWOOD V.J., WHITLOCK J., WITHINGTON V. Classification of antibiotic resistance patterns of indicator bacteria by discriminant analysis: use in predicting the source of fecal contamination in subtropical waters. Appl. Environ. Microbiol. 66, (9), 3698, 2000.

4. SCOTT T.M., ROSE J.B., JENKINS T.M., FARRAH S.R., LUKASIK J. Microbial source tracking: current methodology and future directions. Appl. Environ. Microbiol. 68, (12), 5796, 2002.

5. SHIBATAA T., SOLO-GABRIELEA H.M., FLEMING L.E., ELMIR S. Monitoring marine recreational water quality using multiple microbial indicators in an urban tropical environment. Water Res. 38, 3119, 2004. 
6. CIMENTI M., HUBBERSTEY A., BEWTRA J.K., BISWAS N. Alternative methods in tracking sources of microbial contamination in waters. Water SA, 33, (2), 183, 2007.

7. BERNHARD A..E., FIELD K.G. Identification of Nonpoint Sources of Fecal Pollution in Coastal Waters by Using HostSpecific 16S Ribosomal DNA Genetic Markers from Fecal Anaerobes. Appl. Environ. Microbiol. 66, (4), 1587, 2000.

8. TOROĞLU S., DİNÇER S., KORKMAZ H. Antibiotic resistance in Gram negative bacteria isolated from Aksu River in (Kahramanmaraş) Turkey. Ann. Microbiol. 55, (3), 229, 2005

9. MALIK A., ALEEM A. Incidence of metal and antibiotic resistance in Pseudomonas spp. from the river water, agricultural soil irrigated with waste water and ground water. Environ. Monit. Assess. 178, 293, 2011.

10. NTAKIRUTIMANA T., GANG DU T., GUOU J., HUANG L. Pollution and potential ecological risk assessment of heavy metals in a lake. Pol. J. Environ. Stud. 22, (4), 1129, 2013.

11. MATYAR F., KAYA A., DINÇER S. Antibacterial agents and heavy metal resistance in Gram-negative bacteria isolated from seawater, shrimp and sediment in Iskenderun Bay, Turkey. Sci. Total Environ. 407, 279, 2008.

12. MALIK A., JAISWAL R. Metal resistance in Pseudomonas strains isolated from soil treated with industrial wastewater. World J. Microb. Biot. 16, 177, 2000.

13. ALLEN D.A., AUSTIN B., COLWELL R.R. Antibiotic resistance patterns of metal-tolerant bacteria isolated from an estuary. Antimicrob. Agents Chemother. 12, (4), 545, 1977.

14. ALTUN O., TURKER SACAN M., KIMIRAN ERDEM A. Water quality and heavy metal monitoring in water and sediment samples of the Küçükçekmece Lagoon, Turkey (2002-2003). Environ. Monit. Assess. 151, 345, 2009.

15. APHA-AWWA-WEF Standard methods for the examination of water and wastewater $\left(20^{\text {th }}\right.$ ed.). Washington, DC: APHA, AWWA and WEF (1998).

16. HOLT J.G., KRIEG N.R., SNEATH P.H.A., STANLEY J.T.,WILLIAMS S.T. Bergey's Manual of Determinative Bacteriology, $9^{\text {th }}$ ed.; Williams and Wilkins, Baltimore, 1994.

17. DIONISIO L.P.C., BORREGO J.J. Evaluation of media for the enumeration of faecal streptococci from natural water samples. J. Microbiol Meth. 23, (2), 183, 1995.

18. CALOMIRIS J.J., ARMSTRONG J.L., SEIDLER R.J. Association of metal tolerance with multiple antibiotic resistance of bacteria isolated from drinking water. Appl. Environ. Microbiol. 47, 1238, 1984.

19. KIMIRAN-ERDEM A., ARSLAN E.O, SANLI-YURUDU N.O., ZEYBEK Z., DOGRUOZ N., COTUK A. Isolation and identification of enterococci from seawater samples: assessment of their resistance to antibiotics and heavy metals. Environ. Monit. Assess. 125, (1-3), 219, 2007.

20. BARRY A.L., THORNSBERRY C. Susceptibility testing. In: Manual of clinical microbiology, Lennette E.H., Balows A.W., Hausler J., Truant J.P. (Eds.) Washington, American Society for Microbiology, pp. 561-574, 1981.

21. CLSI - Clinical and Laboratory Standards Institute (CLSI). 2003. Performance standards for antimicrobial disk susceptibility tests; $8^{\text {th }}$ ed., Approved standard M2A8., CLSI, Wayne, PA.

22. KRUMPERMAN P.H. Multiple antibiotic resistance indexing of Escherichia coli to identify high-risk sources of fecal contamination of foods. Appl. Environ. Microbiol. 46, (1), $165,1983$.
23. VIVEKANANDHAN G., SAVITHAMANI K., HATHA A.A.M., LAKSHMANAPERUMALSAMY P. Antibiotic resistance of Aeromonas hydrophila isolated from marketed fish and prawn of South India. Int. J. Food Microbiol. 76, 165, 2002.

24. WASHINGTON J.A., SUTTER V.L. Dilution test procedures. In E. H. Lennette, A. Balows, W. J. Hausler, and J. P. Truant (Eds.), Manual of clinical microbiology (pp. 549555). Washington, District of Columbia: American Society for Microbiology, 1981.

25. AKINBOWALE O.L., PENG H., GRANT P., BARTON M.D. Antibiotic and heavy metal resistance in motile aeromonads and pseudomonads from rainbow trout (Oncorhynchus mykiss) farms in Australia. Int. J. Antimicrob. Ag. 30, 177, 2007.

26. ALVERO C.C. Antibiotic resistance of heterotrophic bacterial flora of two lakes. Syst. Appl. Microbiol. 9, (1-2), 169, 1987.

27. LOBOVA T.I., LISTOVA L.V., YU POPOVA L. Distribution of heterotrophic bacteria in Lake Shira. Microbiology, 73, (1), 89, 2004, Translated from Mikrobiologiya, 73, (1), 105, 2004.

28. SALEEM S., AN K., KAKRU D.K., BANDH S.A., GANAI B.A. Isolation, identification and seasonal distribution bacteria in Dal Lake, Kashmir. JES, 2, (1), 185, 2011.

29. PONTES D.S., PINHEIRO F.A., LIMA-BITTENCOURT C.I., GUEDES R.L.M., CURSINO L., BARBOSA F., SANTOS F.R., CHARTONE-SOUZA E., NASCIMENTO A.M.A. Multiple antimicrobial resistance of Gram-negative bacteria from natural oligotrophic lakes under distinct anthropogenic influence in a tropical region. Microb. Ecol. 58, (4), 762, 2009.

30. LOBOVA T.I., YURIV V., BARKHATOW Y.V., SALAMATINA O.V., POPOVA L.Y. Heterogeneity of heterotrophic bacteria dominating in brackish Lake Shira (Republic of Khakasia, Russia) subjected to anthropogenic impact. JWARP, 2, (5), 389, 2010.

31. KELCH W.J., LEE J.S. Antibiotic resistance patterns of Gram-negative bacteria isolated from environmental sources. Appl. Environ. Microbiol. 36, (3), 450, 1978.

32. FERREIRA DA SILVA M.F., VAZ-MOREIRA I., GONZALEZ-PAJUELO M.,. NUNES O.C., MANAIA $\mathrm{C}^{\prime} . \mathrm{M}$. Antimicrobial resistance patterns in Enterobacteriaceae isolated from an urban wastewater treatment plant. FEMS Microbiol. Ecol. 60, 166, 2007.

33. PARVEEN S., MURPHEE R.L., EDMISTON L., KASPER C.W., PORTIER, K.M. TAMPLIN M.L. Association of multiple antibiotic-resistance profiles with point and nonpoint sources of Escherichia coli in Apalachicola Bay. Appl. Environ. Microbiol. 63, 2607, 1997.

34. ZARATE M.S., GALES A.C., PICÃO R.C., PUJOL G.S., LANZA A., SMAYEVSKY J. Outbreak of OXY-2-producing Klebsiella oxytoca in a renal transplant unit. J. Clin. Microbiol. 46, (6), 2099, 2008.

35. GREWAL J.S., TIWARI R.P. Resistance to metal ions and antibiotics in Escherichia coli isolated from foodstuffs. J. Med. Microbiol. 32, (4), 223, 1990.

36. MCARTHUR J.V., TUCKFIELD R.C. Spatial patterns in antibiotic resistance among stream bacteria: effects of industrial pollution. Appl. Environ. Microbiol. 66, (9), 3722, 2000.

37. MGBEMENA I.C., NNOKWE J.C., ADJEROH L.A., ONYEMEKARA N.N. Resistance of bacteria isolated from Otamiri River to heavy metals and some selected antibiotics. Curr. Res. J. Biol. Sci. 4, (5), 551, 2012. 
38. MIRANDA C.D., ZEMELMAN R. Antimicrobial multiresistance in bacteria isolated from freshwater Chilean salmon farms. Sci. Total Environ., 293, 207, 2002.

39. STEPANAUSKAS R., GLENN T.C., JAGOE C.H., TUCKFIELD R.C., LINDELL A.H., KING C.J., MCARTHUR J.V. Coselection for microbial resistance to metals and antibiotics in freshwater microcosms. Environ. Microbiol. 8, (9), 1510, 2006.
40. WRIGHT M.S., PELTIER G.L., STEPANAUSKAS R., MCARTHUR J.V. Bacterial tolerances to metals and antibiotics in metal-contaminated and reference streams. FEMS Microbiol. Ecol. 58, 293, 2006.

41. HASSAN S.H.A., ABSKHARON R.N.N., GAD EL-RAB S.M.F., SHOREIT A.A.M. Isolation, characterization of heavy metal resistant strain of Pseudomonas aeruginosa isolated from polluted sites in Assiut city, Egypt. J. Basic Microbiol. 48, 168, 2008. 